\title{
ZOONOTIC SURVEILANCE (BRUCELLOSIS) IN ENREKANG DISTRICT SOUTH SULAWESI PROVINCE
}

\section{Surveilance Zoonotik Lainnya (Brucellosis) di Kabupaten Enrekang Provinsi Sulawesi Selatan}

\author{
Nur Alim Ahzan*, Muhasirah, Nurhayati, Rosmiaty \\ BTKLPP Kelas I Makassar, Dirjen P2P Kementerian Kesehatan R.I.
}

Alamat Korespondensi : alimahzan@gmail.com

\section{Article Info \\ Article History \\ Received: 26 Juli 2021 \\ Revised : 16 Agustus 2021 \\ Accepted : 20 Agustus 2021}

\section{Keywords :}

Brucellosis, Survailance, rbt, pcr, enrekang

\section{Kata kunci :}

Brucellosis, surveilans, rbt, pcr, enrekang

\section{ABSTRACT / ABSTRAK}

Brucellosis is a zoonotic disease caused by bacteria of the genus brucella, brucellosis can be transmitted from animals to humans. The purpose of the study was to determine the risk of brucellosis transmission to breeders, livestock workers and animal health workers in Enrekang district, South Sulawesi Province. Methods Blood samples were taken using an analyst with a vacutainer tube, then centrifuged and left at room temperature until serum was formed. The serum was then dripped with RBT on the slide, the positive RBT result was then tested for confirmation with conventional PCR at the Laboratory of Environmental Health Engineering and Disease Control Class I Makassar. The results of the study based on the RBT (Rose Bengal Test) obtained 3 positive samples with a positive category of +++ and 1 sample with a positive category of ++ . and after confirming the sample using the Conventional PCR method, 2 positive samples were obtained. Conclusion: There are cases of brucellosis transmission to farmers and animal health workers in Enrekang district.

Brucellosis merupakan penyakit zoonosis yang disebabkan oleh bakteri genus brucella, brucellosis dapat menular dari hewan ke manusia. Tujuan penelitian untuk mengetahui risiko penularan brucellosis pada peternak, pekerja peternakan dan petugas kesehatan hewan di Kabupaten Enrekang Propinsi Sulawesi Selatan. Metode Sampel darah diambil dengan menggunakan tenaga analis dengan tabung vakutainer, kemudian dilakukan centrifuge dan dibiarkan pada temperatur kamar sampai terbentuk serum. Serum kemudian di tetesi dengan RBT pada slide, hasil RBT positif kemudian diuji konfirmasi dengan dengan PCR-Konvensional di Laboratorium Balai Teknik Kesehatan Lingkungan dan Pengendalian Penyakit Kelas I Makassar. Hasil penelitian berdasarkan uji RBT (Rose Bengal Test) didapatkan 3 sampel positif dengan kategori positif +++ dan 1 sampel dengan kategori positif ++. dan setelah dilakukan uji konfirmasi terhadap sampel dengan metode PCR Konvensional didapatkan 2 sampel positif. Kesimpulan: Terdapat kasus penularan brucellosis pada peternak dan petugas kesehatan hewan di Kabupaten Enrekang. 


\section{PENDAHULUAN}

Brucellosis merupakan penyakit zoonosis yang disebabkan oleh bakteri genus brucella. Brucellosis di Indonesia dikenal sebagai penyakit reproduksi menular pada ternak, tetapi penyakit ini dapat menular pada manusia. Penyakit ini belum banyak dikenal di masyarakat. Hewan yang terinfeksi kuman brucella dapat mengalami abortus, retensi plasenta, orchitis dan epidiniitis serta dapat mengekskresikan kuman ke dalam uterus dan susu.

Penularan penyakit ke manusia terjadi nielalui komsumsi susu dan produk susu yang tidak dipasteurisasi atau melalui membrana mukosa dan kulit yang luka. Berat ringannya penyakit tergantung strain brucella yang menginfeksi. Brucella abortus, B.melitensis, B. suis dan $B$. canis adalah strain yang patogen ke manusia . Gejala klinis brucellosis pada manusia yaitu demam intermiten, sakit kepala, lemah, arthralgia, myalgia dan turunnya berat badan . Komplikasi penyakit dapat terjadi berupa arthritis, endokarditis, hepatitis granulona, meningitis, orchitisdan osteomyelitis serta dilaporkan dapat pula mengakibatkan abortus pada wanita hamil . Diagnosis brucellosis dilakukan dengan isolasi Brucella spesies dalam darah dan urin serta uji serologis.

Brucellosis pada manusia banyak terjadi di daerah Mediteranean, Asia bagian Barat, sebagian Afrika dan Amerika Latin (AMATO, 1995). Jumlah kejadian brucellosis pada manusia yang sebenarnya belum diketahui tetapi berdasarkan laporan kejadian penyakit di daerah endemis bervariasi yaitu kurang dari 0,01 sampai lebih dari 200 kasus per 100.000 orang (MERINO, 1989).

Kejadian brucellosis pada manusia di Indonesia belum pernah dilaporkan karena kurangnya publikasi brucellosis sebagai penyakit zoonosis yang mengakibatkan sebagian besar masyarakat tidak mengetahui jika brucellosis dapat menular dari hewan ke manusia. Kejadian brucellosis pada manusia di Indonesia perlu segera diantisipasi karena dari hasil uji serologis yang dilakukan oleh BBLitvet terhadap para pekerja kandang sapi perah, kandang babi dan RPH babi di DKI Jakarta terdeteksi adanya titer antibodi terhadap kuman brucella sp. (SUDIBYO, 1995). Tingginya angka prevalensi brucellosis pada ternak di Indonesia yang mencapai $40 \%$ dan menyebar hampir di seluruh propinsi di Indonesia memungkinkan untuk terjadinya penularan brucellosis ke manusia.

Brucellosis pada hewan sudah bersifat endemis di Indonesia dan kadang-kadang muncul sebagai epidemi pada banyak peternakan sapi perah di Jakarta, Bandung, Jawa Tengah dan Jawa Timur. Prevalensi antar wilayah di Indonesia sangat bervariasi tergantung manajemen pemeliharaan. Beberapa wilayah seperti Bali, Pulau Lombok, Pulau Kalimantan, Sumatera bagian tengah (Riau, Kepulauan Riau, Jambi dan Sumatera Barat) telah dinyatakan bebas Brucellosis. Sedangkan bagian Sumatera lainnya sedang dalam persiapan menuju pembebasan Brucellosis (Dirkeswan 2004)

Kejadian Brucellosis pada laki -laki lebih sering terjadi dari pada wanita dengan rasio $5: 2$ sampai 5 : 3 didaerah endemis. Kejadian brucellosis juga banyak terjadi pada usia 30-50 tahun. Hal ini berkaitan dengan usia produktif dan yang berkecimpung didunia peternakan kebanyakan adalah laki -laki. Pada anak -anak, kejadian brucellosis didunia mencapai 3-10 \% didaerah endemis brucellosis. Pada orang tua biasanya bersifat kronis (Noor 2006).

Berdasarkan data laporan BBVet Maros tahun 2018 situasi kasus brucellosis pada hewan dan manusia tersebar di Provinsi Sulawesi Selatan dan Tenggara, di Propinsi Sulawesi Selatan daerah yang endemis brucellosis adalah Kabupaten Enrekang dan Pinrang. Data Kasus kejadian brucellosis pada manusia di Provinsi Sulawesi Selatan masih belum dapat diketahui secara pasti karena belum adanya laporan kasus yang tercatat di Dinas Kesehatan Kabupaten maupun Dinas Kesehatan Propinsi.

Berdasarkan pertimbangan tersebut maka pada tahun 2021 BTKLPP Kelas I Makassar akan 
melakukan surveilans terhadap para peternak, pekerja peternakan, produk peternakan dan petugas kesehatan hewan terhadap kejadian brucellosis pada manusia dengan tujuan agar masyarakat mengenal brucellosis sebagai penyakit zoonosis yang dapat menular dari hewan ke manusia.

Penelitian ini bertujuan untuk mengetahui gambaran risiko penularan brucellosis pada peternak, pekerja peternakan dan petugas kesehatan hewan di Kabupaten Enrekang Provinsi Sulawesi Selatan.

\section{BAHAN DAN METODE}

Jenis penelitian adalah penelitian deskriptif dengan pendekatan observasional. Lokasi penelitian adalah di Kabupaten Enrekang yang dilaksanakan pada bulan Maret 2021. Populasi penelitian adalah seluruh peternak di Kabupaten Enrekang dan Sampel peneltian adalah peternak dan petugas kesehatan hewan terpilih di Kecamatan Maiwa, Cendana dan Enrekang dengan jumlah 258 sampel. Teknik sampling adalah dengan kuota sampling. Teknik pengumpulan data adalah data primer yaitu yang diperoleh langsung dilapangan dan data sekunder berupa data pendukung lainnya. Analisa data dilakukan secara deskriptif untuk memperoleh gambaran penularan brucellosis. Penyajian data dalam bentuk tabel yang disertai narasi dan pembahasan. Penelitian ini menggunakan bahan berupa RBT (rose bengal test) dengan cara kerja yaitu darah diambil dengan menggunakan tenaga analis dengan tabung vakutainer, kemudian dilakukan centrifuge dan dibiarkan pada temperatur kamar sampai terbentuk serum. Serum kemudian di tetesi dengan RBT pada slide, hasil RBT positif kemudian diuji konfirmasi dengan dengan PCR-Konvensional di Laboratorium Balai Teknik Kesehatan Lingkungan dan Pengendalian Penyakit Kelas I Makassar.

\section{HASIL}

Surveilans zoonotic lainnya (brucellosis) ini dilaksanakan pada tanggal 15-20 Maret 2021. Pengumpulan data dilakukan dengan pengambilan sampel darah vena dan wawancara menggunakan quisioner. Lokasi surveilans adalah di tiga kecamatan yaitu Kecamatan Maiwa, Cendana dan Enrekang yang merupakan sentra peternakan dengan populasi terbanyak. Lokasi surveilans dapat dilihat pada peta berikut:

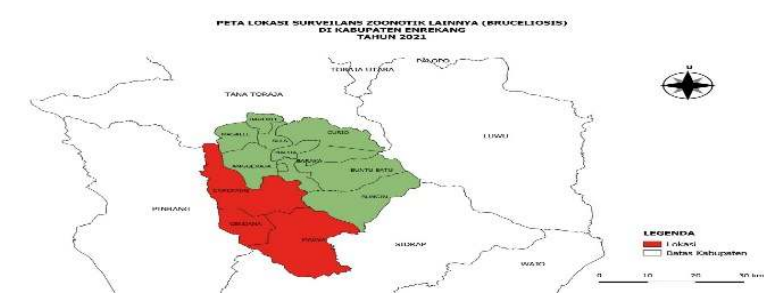

Gambar 1 : Lokasi Surveilans zoonotic lainnya (brucellosis) di Kabupaten Enrekang.

Karakteristik responden disajikan dalam bentuk tabel berdasarkan jenis kelamin, umur, jenis pekerjaan dan jenis Pendidikan. Responden terdiri dari 258 orang terdiri dari laki-laki 191 dan perempuan 67 dengan rentang umur antara 12 hingga 72 tahun. Berdasarkan jenis kelamin didapatkan laki-laki sebanyak 191 (74.0\%) dan Perempuan 67 (24.0\%). Bila diklasifikasikan umur 17 sampai dengan 55 tahun yang paling banyak yaitu 203 orang $(78.7 \%)$ yang merupakan kelompok usia produktif. Pada aspek jenis pekerjaan didapatkan rata-rata bekerja pada sector peternakan dengan jenis Pendidikan terbanyak adalah SMU/K (tabel 1 ).

Pada penelitian ini untuk mendeteksi ada tidaknya kejadian brucellosis pada peternak, petugas/pekerja peternakan dan petugas kesehatan hewan di Kabupaten Enrekang, sampel darah yang diambil dari 258 orang peternak dari lokasi penelitian (Kecamatan Maiwa, Cendana dan Enrekang) yang diperiksa dengan Rose Bengal Test (RBT) dan PCR-Konvensional.

Berdasarkan data hasil uji di atas menunjukkan bahwa hasil uji RBT dari Kecamatan Maiwa terdapat 1 (2.9\%) positif dari total 35 sampel yang diperiksa dan 1 (6.6\%) sampel positif dari total 15 sampel yang di PCR-Konvensional. Sampel yang diperiksa di Kecamatan Cendana tidak terdapat sampel yang positif, sedangkan sampel yang diperiksa di Kecamatan Enrekang terdapat $3(2.4 \%)$ sampel positif RBT dari total 124 sampel dan hanya $1(0.8 \%)$ 
yang positif PCR-Konvensional dari 30 sampel yang di PCR-Konvensional (tabel 2).

\section{Tabel 1. Karakteristik Responden}

\begin{tabular}{lcc}
\hline \multirow{2}{*}{ Karakteristik } & \multicolumn{2}{c}{ Responden } \\
\cline { 2 - 3 } Jenis Kelamin & $\mathbf{n}$ & $\%$ \\
\hline Laki-laki & & \\
\hline Perempuan & 191 & 74,0 \\
\hline Umur (tahun) & 67 & 24,0 \\
\hline $12-18$ & & \\
$17-25$ & 4 & 1,6 \\
\hline $26-36$ & 20 & 7,8 \\
\hline $36-45$ & 44 & 17,1 \\
\hline $46-55$ & 62 & 24,0 \\
\hline $56-65$ & 77 & 29,8 \\
\hline$>65$ & 3 & 12,8 \\
\hline Jenis Pekerjaan & 18 & 7,0 \\
\hline Peternak & & \\
\hline Petani/peternak & 33 & 12,7 \\
\hline Pekerja peternakan & 52 & 20,2 \\
\hline Petugas Keswan & 124 & 48,1 \\
\hline Lainnya & 35 & 13,6 \\
\hline Jenis Pendidikan & 14 & 5,4 \\
\hline Tidak tamat SD & & \\
\hline SD & 5 & 1,9 \\
\hline SMP & 32 & 12,4 \\
\hline SMU/K & 42 & 16,3 \\
\hline D1 & 118 & 45,7 \\
\hline S1 & 2 & 0,8 \\
\hline S2 & 57 & 22,1 \\
\hline Total & 2 & 0,8 \\
\hline Sumber Data primer & $\mathbf{2 5 8}$ & $\mathbf{1 0 0 , 0}$ \\
\hline
\end{tabular}

Sumber: Data primer, 2021

Tabel 2. Hasil uji RBT dan PCR Responden

\begin{tabular}{ccc}
\hline \multirow{2}{*}{ Kecamatan } & \multicolumn{2}{c}{ Hasil Uji Sampel } \\
\cline { 2 - 3 } & RBT & PCR-Konv. \\
\hline Maiwa & 1 & 1 \\
Positif & 34 & 14 \\
Negatif & & \\
Cendana & 0 & 0 \\
Positif & 99 & 15 \\
Negatif & & \\
Enrekang & 3 & 1 \\
\hline Positif & 121 & 29 \\
Negatif & 258 & 60 \\
\hline Total &
\end{tabular}

Sumber: Data Primer 2021

\section{PEMBAHASAN}

Brucellosis merupakan penyakit menular dari hewan ke manusia yang menyerang pada semua jenis kelamin. Brucellosis kebanyakan berisiko pada pekerjaan tertentu terutama pada peternak dan petugas kesehatan hewan yang menangani brucellosis dan sebagian besar terkena pada laki-laki yang berusia antara 20 dan 45 tahun. Berdasarkan hasil survei yang dilakukan di Kab. Enrekang menujukkan bahwa umur terbanyak dari hasil survei adalah antara $36-55$ tahun $53.9 \%$. Hasil penelitian ini sama dengan yang dilakukan oleh Young (2016) yang mengatakan bahwa, brucellosis dapat menyerang manusia dari semua umur dan jenis kelamin. Namun sebagai penyakit yang terkait pekerjaan biasanya laki-laki berusia antara 20-60 tahun memiliki risiko yang lebih besar. Kejadian brucellosis pada laki-laki lebih sering terjadi dari pada wanita dengan rasio mencapai $5: 2$ sampai 5 : 3 di daerah endemis. Selain itu, kejadian brucellosis juga banyak terjadi pada usia 30 - 50 tahun. Hal ini kemungkinan disebabkan karena sebagian besar yang berkecimpung di peternakan kebanyakan laki-laki dan pada usia produktif.

Hasil survei di Kabupaten Enrekang menujukkan bahwa jenis kelamin yang paling banyak berkecimpung pada peternakan adalah laki-laki yaitu $74 \%$, dan didominasi oleh jenis pekerjaan sebagai pekerja peternakan (48\%), dengan tingkat pendidikan tamatan SMU/K $(45,7 \%)$. Berbeda dengan hasil identifikasi brucellosis pada peternak yang menemukan bahwa kejadian brucellosis di dunia mencapai 3 $10 \%$ di daerah endemis brucellosis dan pada orang tua, brucellosis biasanya bersifat kronis (Young dalam Nusantara Medical Science Journal 1, 2017).

Gejala klinis brucellosis pada manusia akan berbeda tergantung dari sifat infeksinya, yaitu infeksi laten, brucellosis akut, brucellosis sub akut dan brucellosis kronis. Berdasarkan hasil survei menunjukkan bahwa dari semua gejala yang ditanyakan kepada responden sebagian besar menyatakan tidak mengalami gejala seperti demam intermitten, sakit kepala, nyeri otot, sakit pinggang, sakit perut, berkeringat banyak, nafsu makan berkurang dan tidak ada satupun 
responden yang mengalami pembengkakan pada scrotum dan lutut serta mengalami penurunan berat badan secara tiba-tiba.

Hewan yang terinfeksi jika melewati daerah penduduk dapat menghasilkan kontaminasi berat pada jalan, pekarangan, atau pasar, terutama jika abortus terjadi. Sumber air seperti sumur, juga dapat menyebabkan kontaminasi dari hewan yang baru saja mengalami abortus atau dengan run-off air hujan dari daerah yang terkontaminasi. Kondisi kandang sapi yang dimiliki peternak sapi dalam penelitian sangat dekat dengan tempat mereka tinggal dan berinteraksi sehari-hari, beberapa peternak biasa melakukan aktivitas makan dan minum di dalam kandang serta saat membersihkan kandang peternak tidak dilengkapi dengan biosecurity (APD) yang cukup.

Berdasarkan hasil uji RBT (Rose Bengal Test) pada responden yang positif brucellosis menunjukkan bahwa sampel yang positif adalah pekerja peternakan 1 orang yang setiap hari kontak dengan hewan ternak, dan sering melakukan penanganan terhadap hewan yang sakit ataupun jika terjadi keguguran (abortus pada sapi) sehingga sangat berisiko terinfeksi dengan brucellosis. Demikian juga dengan 1 orang peternak yang hasil uji RBTnya positif adalah peternak yang sudah sejak lama beternak dan pernah kontak dengan ternak yang yang mengalami keguguran dan setelah dilakukan uji lanjutan untuk konfirmasi dengan metode PCR konvensional kedua responden tersebut menunjukkan hasil yang positif.

Brucellosis memiliki dampak ekonomi sangat tinggi berkaitan dengan rendahnya produktivitas hewan penderita dan pada manusia tingginya biaya pengobatan akibat durasi pengobatan yang lama. Brucellosis merupakan salah satu penyakit hewan menular strategis karena penularannya sangat cepat antar batas dan lintas daerah, sehingga memerlukan pengaturan lalu lintas hewan yang ketat. Pada penelitian yang sama yaitu Identifikasi Brucellosis pada Peternak di Kabupaten Pinrang yang pernah dilakukan oleh Lucia Muslimin dkk dengan metode RBT dan CFT didapatkan banyak peternak yang hasil ujinya positif.
Hasil uji RBT terhadap 2 orang petugas kesehatan hewan menunjukkan hasil yang positif RBT yang sering menangani inseminasi buatan dan vaksinasi brucellosis terhadap hewan ternak yang bekerja pada Dinas Peternakan dan Perikanan Kabupaten Enrekang pada bagian Kesehatan Hewan akan tetapi setelah dilakukan uji konfirmasi dengan metode PCR Konvensional hasinya menunjukkan negatif antigen brucellosis, akan tetapi hasil PCR yang negatif ini masih perlu dilakukan uji lanjutan (ulangan) setelah 3 bulan kemudian untuk lebih memastikan apakah petugas tersebut benar-benar tidak terinfeksi kuman brucella sp. Oleh karena survey yang dilakukan ini adalah survei awal untuk skrining penyakit zoonotic lainnya (brucellosis) pada peternak dan pekerja peternakan serta produk peternakan.

Berdasarkan hasil uji laboratorium sampel produk peternakan yaitu dangke dan susu sapi menunjukkan hasil yang negative, hal ini menunjukkan bahwa retensi brucella terhadap susu yang dihasilkan oleh sapi belum terjadi sehingga produk susu dan dangke masih aman untuk dikomsumsi, namun demikian jika hewan ternak yang sakit dan memiliki gejala mirip brucellosis maka semua produk hewannya tidak boleh dikonsumsi sama sekali dan semua isi perut hewan tersebut harus dimusnahkan agar tidak terjadi penularan brucellosis.

\section{KESIMPULAN DAN SARAN}

Hasil uji sampel menunjukkan bahwa terdapat 4 sampel yang positif RBT yaitu 1 (satu) orang pekerja peternakan, 1 (satu) orang peternak dan 2 (dua) orang petugas kesehatan hewan dan setelah dilakukan uji lanjutan untuk konfirmasi dengan metode PCR-Konvensional menunjukkan bahwa hanya 2 sampel yang positif brucellosis hal ini menunjukkan bahwa terdapat kasus penularan brucellosis pada peternak dan petugas peternakan.

Perlunya dilakukan pengobatan terhadap sampel yang yang positif brucellosis dengan antibiotik sesuai dengan resep dokter dan diberikan selama minimal 6 minggu atau sesuai 
dengan petunjuk petugas Kesehatan yang menangani.

Untuk mencegah terjadinya kasus brucellosis semakin menyebar perlu dilakukan surveilans lanjutan dengan bekerja sama dengan semua lintas program dan sektor terkait.

Dinas Peternakan dan Perikanan Kabupaten Enrekang sebaiknya melakukan skrining secara rutin terhadap petugas kesehatan hewan serta hewan ternak yang masuk di Kabupaten Enrekang untuk mencegah penularan brucellosis.

\section{DAFTAR PUSTAKA}

Herwandi, Novia. Kejadian dan Faktor Risiko Brucellosis pada Peternak dan Pekerja Peternakan Sapi Perah di Kabupaten Sleman [Tesis]. Program Pascasarjana UGM: Yogyakarta. 2012

Lucia Muslimin, Andi Tenrigau Bangsawan, Sri Utami. Department of Veterinary, Faculty of Medicine, Hasanuddin University, Department of Animal Quarantine, Pare Pare Identifikasi Brucellosis Pada Peternak Sapi di Kabupaten Pinrang

Menteri Kesehatan Republik Indonesia. 2010. Peraturan Menteri Kesehatan Republik Indonesia No. 1501/MENKES/PER/X/2010 tentang Jenis Penyakit Menular Tertentu yang Dapat Menimbulkan Wabah dan Upaya Penanggulangan. Jakarta: (tidak diterbitkan).

Noor, S.M. Brucellosis: Penyakit Yang Belum Banyak Dikenal di Indonesia. Wartazoa
Vol.16 No. 1. 2006 Shretsha, S. Brucella and Brucellosis, Medchrome Online Medical Magazine, $M$ edchrome Inc. [Internet]. Tersedia pada: http://medchrome.com/basicsience/microbi ology /brucella-and-brucellosis/ .2011 [Diakses 24 April 2016].

Notoatmojo, Sukijo, 2005, Metodologi Penelitian Kesehatan, Rineka Cipta

Sudibyo, A. Isolasi dan Identifikasi Brucella Abortus yang Menyerang Sapi Perah di Daerah Khusus Ibukota Jakarta. Pros. Seminar Nasional Peternakan dan Veteriner. 7-8 November. Cisarua. Bogor. 1995

Susan M. Noor, Pratiwi Sudharmono, Asmarani Kusumawati, dan Anis Karuniawati, Deteksi Brucellosis pada Susu Sapi dengan Uji PCR, Departemen Bakteriologi Balai Besar Penelitian Veteriner, Bogor 2Departemen Mikrobiologi Fakultas Kedokteran Universitas Indonesia, Jakarta 3Bagian Reproduksi dan Kebidanan Fakultas Kedokteran Hewan Universitas Gadjah Mada, Yogyakarta

Wayan, 2016 Kertanegara Balai Karantina Pertanian Kelas II Kendari, Badan Karantina Pertanian. Resiko Penyebaran Brucellosisis di Sulawesi Tenggara

Young, J.E. Brucellosis, In: Brachman, P.S., Abrutyn, E., (Eds), Bacterial Infections of Humans, Epidemiology and Control, Fourth Edition. Springer Science+Bussines Media, New York. 2009 